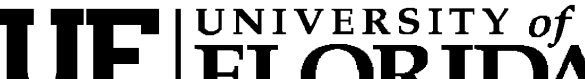 FLORIDA \\ IFAS Extension
}

\section{Specialty Meat Marketing Claims: What's the Difference? ${ }^{1}$}

\section{Chad Carr, Larry Eubanks, and Ryan Dijkhuis ${ }^{2}$}

American consumers are confused about the differences between meat products with special marketing claims (i.e. organic, natural, naturally raised, and grass-fed) and regular or commodity meat products. The following report will discuss these production/marketing claims as defined by the USDA and address the differences between these products for food safety, human health, and eating quality.

\section{USDA Organic}

The U.S. Congress passed the Organic Foods Production Act (OFPA) in 1990. The OFPA and the National Organic Program (NOP) are housed within the Agricultural Marketing Service of the USDA and collectively serve as the governing body of administering the standards for Organic agricultural products. A USDA-accredited state or private organization often serves as the on-site certifier at the farm and/or production site. The homepage for the National Organic Program is http://www.ams.usda.gov/nop/indexIE.htm. The following subheadings and bullets will address some of the most important points of the NOP.

\section{Organic Crop Production}

The regulations for organic livestock production are dependent upon the regulation for organic crop production. The USDA Organic crops production standards are as follows:

- Crops must be raised without most conventional pesticides, petroleum-based fertilizers, or sewage sludge-based fertilizers.

- Crop land must have no prohibited substances applied to it for at least 3 years before the harvest of an organic crop.

- The use of genetic engineering (hybrid corn) and ionizing radiation (irradiation) is prohibited.

- Soil fertility will be managed through tillage and cultivation practices, crop rotations, and cover crops, and will be supplemented with animal and crop waste materials and allowed synthetic materials.

\section{Organic Livestock and Poultry Production}

The USDA Organic livestock and poultry production standards are as follows:

1. This document is AN191, one of a series of the Animal Science Department, Florida Cooperative Extension Service, Institute of Food and Agricultural Sciences, University of Florida. Original publication date September, 2007. Reviewed February, 2008. Visit the EDIS Web Site at http://edis.ifas.ufl.edu.

2. Chad Carr, Assistant Professor; Larry Eubanks, Coordinator of Research Programs; and Ryan Dijkhuis, Biological Scientist; Department of Animal Sciences, Cooperative Extension Service, UF/IFAS, Gainesville, FL 32611.

The Institute of Food and Agricultural Sciences (IFAS) is an Equal Opportunity Institution authorized to provide research, educational information and other services only to individuals and institutions that function with non-discrimination with respect to race, creed, color, religion, age, disability, sex, sexual orientation, marital status, national origin, political opinions or affiliations. U.S. Department of Agriculture, Cooperative Extension Service, University of Florida, IFAS, Florida A. \& M. University Cooperative Extension Program, and Boards of County Commissioners Cooperating. Millie FerrerChancy, Interim Dean 
- Meat animals must be raised under organic management from the last third of gestation, or no later than the second day of life for poultry.

- Meat animals and poultry must be fed 100 percent USDA Organic grain and/or forage diets. The standards will allow certain vitamin and mineral supplements.

- Meat animals and poultry may not be growth-implanted, fed growth promotants, fed diets containing urea, or given or fed antibiotics for any reason.

- Meat animals and poultry may not be given paraciticides (i.e. de-wormer) for any period of production. Additionally, dams may not be given paraciticides during the last third of gestation or during lactation.

- Meat animals and poultry may be vaccinated.

- All animals must have access to the outdoors, including access to pasture for ruminants.

The National List of Allowed and Prohibited Substances is available online at: http://www.ams.usda.gov/nop/NOP/standards/ ListReg.html.

\section{Who Needs To Be Certified?}

- All operations whose gross income from organic sales is greater than $\$ 5,000$ must be certified by USDA-accredited agents to label products as USDA Organic.

\section{Packaging and Labeling Products as USDA Organic}

Guidelines for labeling and packaging include:

- The USDA Organic seal can only be advertised on products that have at least 95 percent organic ingredients.

- Processors must prevent organic and non-organic products from commingling and should protect organic products from contacting prohibited substances.
- Other products can state that they were made with organic products, but cannot display the USDA symbol.

- If USDA officials find that someone knowingly sells or mislabels an ineligible product as USDA Organic, the penalty can be up to $\$ 11,000$.

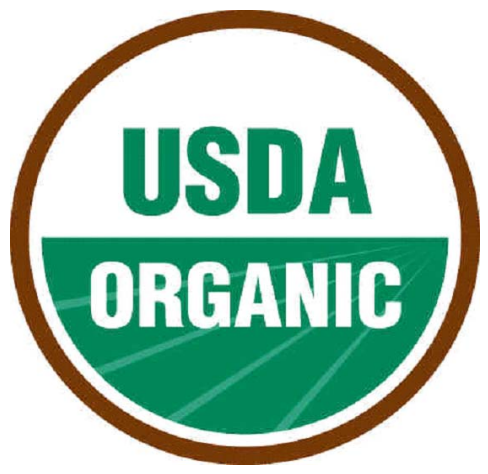

Figure 1. USDA Organic seal.

\section{Natural and Naturally Raised or Produced}

\section{Defining Natural}

In 1982, the USDA Food Safety Inspection Service (FSIS) determined it should develop a definition of a "natural" meat or poultry product to guarantee the accuracy of product labels and advertising. FSIS defined a "natural" product as:

- "Any product which is not more than minimally processed and does not contain artificial flavor or coloring, chemical preservatives, or any other artificial ingredient."

- Minimal processing "does not alter the raw product, but only separates the food into component parts "-like grinding or chopping.

This definition only addresses the processes and ingredients used to make the meat or poultry product. Essentially all fresh meat would be termed "natural" under this definition. The FSIS definition of "natural" processing is getting confused with the numerous products which claim to come from "naturally raised" or "naturally produced" livestock. 


\section{Defining "Naturally Raised or Produced"}

The FSIS definition of "natural" says nothing about how an animal can or should be raised. Currently, meat processors submit "naturally raised" or "naturally produced" claims to FSIS for labeling, even though there is no minimum standard for these claims. FSIS handles each product on a case-by-case basis and generally relies on producer testimonials, production records, and affidavits to provide evidence for the proposed label. Because there is no definition, the Agricultural Marketing Service (AMS) division of the USDA has been gathering information to determine what "naturally raised" or "naturally produced" should mean. On November 28, 2007, The AMS division of the USDA released a suggested set of standards for "naturally raised" livestock and products derived from such livestock. More information about defining "naturally raised" or "naturally produced" can be found at http://www.ams.usda.gov/lsg/stand/NRnotice1107.pdf

\section{USDA Process Verification}

AMS personnel will develop the new "naturally raised" or "naturally produced" definition into a Quality System Verification Program (QSVP) or Process Verified Procedure. USDA process verification has been around since 1978, when Certified Angus Beef became the first USDA-Certified program. A USDA Certification program is very similar to a Process Verified QSVP program. The primary difference is that certification evaluates products on a predetermined standard of quality (marbling, color, etc.), while process verification applies to total production-processing-distribution systems that deliver products with desirable quality.

Currently, any process or operation associated with livestock production or meat processing can be part of a Process Verified Procedure. However, the new "naturally raised" or "naturally produced" definition will have a minimum process standard which must be reached for verification.

Process verification requires:
- Producers or processors to submit a documented quality management program covering all aspects of their system which must be approved by AMS to be declared "USDA Verified."

- The verified portions of the process to be periodically audited by AMS.

More information about process verification can be found at http://processverified.usda.gov/ or http://www.nichepork.org/documents/ certificationguide.pdf.

\section{What does the New Preliminary USDA Standard State?}

The new suggested standard states that in order to sell animal products as "naturally raised," animals must be raised entirely without:

- Growth promotants

- Antibiotics

- Mammalian or avian by-products

However, according to these production suggestions, animals can be administered:

- Parasite control products (de-wormer)

- Vaccinations

- Bloat prevention and treatment products (feed grade probiotics or buffers)

Many small producers and small meat business entrepreneurs hoped that the USDA would establish a directive stating that products marketed as naturally raised could not be raised in a concentrated animal feeding operation (CAFO). A CAFO is a facility that feeds animals in a confined area for 45 days or more during any 12-month period. However, neither animal concentration nor access to pasture or the outside were addressed in the proposed directive. Comments on these suggestions by individuals were accepted by the USDA until January 28, 2008 at http://www.regulations.gov/fdmspublic/component/ main?main=DocketDetail\&d=AMS-LS-07-0131 . 


\section{Grass-Fed}

\section{Defining Grass-Fed}

The AMS division of USDA released the established standard to market meat from "grass-fed" livestock on October 16, 2007. This new directive is now used by AMS personnel as the definition producers and processors must adhere to for "grass-fed" as a Process Verified Procedure. More information about "grass-fed" products as well as the finalized standard can be found at http://www.ams.usda.gov/lsg/stand/ GrassFed101607.pdf.

\section{What does the Finalized USDA Standard State?}

The new standard states that in order to sell products as "grass-fed," post-weaning ruminant animals must be fed only:

- Forage from pasture

\section{OR}

- Harvested forage

The new standard also specifies that all animals whose products are marketed as "grass-fed" must have continuous access to pasture during the growing season. Additionally, if animals accidentally consumed grain or were supplemented grain during harsh weather conditions to maintain their well being, the amount and frequency of grain supplementation must be documented explicitly. The entire document as listed in the federal register can be found at http://www.ams.usda.gov/lsg/stand/ GrassFed101607.pdf.

\section{Differences Between Specialty and Commodity Products}

\section{Food Safety and Human Health}

The USDA requires honest labeling and advertising. Meat products from USDA Organically raised, "naturally raised," or "grass-fed" animals were definitely raised differently than products from regular animals. Additionally, USDA Organic meat products were definitely processed independent of non-organic products. Very little scientific research has been conducted comparing the safety, nutritional value, or eating quality of specialty products and commodity products. Even so, the research that has been conducted has no evidence that specialty meat products are safer or more nutritious than commodity meat products (Honikel, 1998). Therefore, the USDA makes no claims stating that these specialty products are different.

\section{Grass-Fed vs. Grain-Fed}

Diet affects how much fat an animal will deposit. Since grass and hay is much less energy dense than grain:

- Grass-fed beef is normally leaner, both externally and within the muscle (marbling) and has less saturated fat and cholesterol (Hedrick et al., 1983).

- However, if animals are fed the same feedstuffs, (i.e. Organic corn vs. commodity corn) those products will not be different relative to fat content.

\section{Eating Quality}

If animals are fed the same feedstuffs, there will be very little if any difference in eating quality of meat products of animals raised conventionally, organically, or naturally. However, since grass-fed animals are leaner than grain-fed animals this affects eating quality. Generally, cooked products from grass-fed animals as compared to grain-fed animals will:

- Taste distinctly different or have a higher incidence of "off-flavors" - due to the association of fat with desirable flavor.

- Tend to be tougher - because marbling contributes to tenderness and grass-fed animals grow slower and are generally older than grain-fed animals.

- Tend to be less juicy - because when marbling melts during cooking it contributes to juiciness.

All of these findings are well established and cited by numerous authors (Regan et al., 1977; Hedrick et al., 1983; Crouse et al., 1984). 


\section{Conventionally Raised vs. Organically or Naturally Raised}

Anything an animal is fed or administered can exist in its body tissues. However, the Food and Drug Administration requires all animals to be withdrawn from antibiotics for a specified period prior to harvest. Even so:

- Commodity products can have slightly higher residual antibiotic levels than organic or naturally raised products, however, research shows this minimal increase will not lead to human antibiotic resistance.

The USDA allows ruminant animals (cattle, sheep, and goats) to be implanted with hormonal growth promotants. Therefore:

- Commodity products can have higher residual estrogen levels than organic or naturally raised products, however, all research shows this minimal increase has no affect on human health (Kuipper-Goodman, 1998 and Kouba, 2003).

\section{Conclusions}

Unquestionably, the U.S. meat industry provides consumers the safest products in the world, regardless of production method, and consumers should feel overwhelmingly confident as they make their purchasing decisions.

\section{Literature Cited}

Crouse, J. D., H. R. Cross, and S. C. Seideman. 1984. Effects of a Grass or Grain Diet on the Quality of Three Beef Muscles. J. Anim. Sci. 58: 619-625.

Hedrick, H. B., J. A. Paterson, A. G. Matches, J. D. Thomas, R. E. Morrow, W. G. Stringer, and R. J. Lipsey. 1983. Carcass and Palatability Characteristics of Beef Produced on Pasture, Corn Silage and Corn Grain. J. Anim. Sci. 57: 791-801.

Honikel, K. O. 1998. Quality of ecologically produced foods of animal origin. Dtsch. Tierarztl. Wschr. 105: 327-329.

Kouba, M. 2003. Quality of organic animal products. Livestock Prod. Sci. 80: 33-40.
Kuipper-Goodman, T. 1998. Food safety: mycotoxins and phycotoxins in perspective. In: Mycotoxins and Phycotoxins- developments in chemistry, toxicology and food safety. Edited by M. Miraglia, H. van Egmont, C. Brera, and J. Gilbert. IUPAC.

National Pork Board. 2006. Certification Guide. Des Moines, IA.

http://www.nichepork.org/documents/ certificationguide.pdf. Accessed September 7, 2007.

Reagan, J. O., J. A. Carpenter, F. T. Bauer, and R. S. Lowrey. 1977. Packaging and Palatability Characteristics of Grass and Grass-Grain Fed Beef. J. Anim. Sci. 45: 716-721.

U.S.D.A. 2000. National Organic Program. Washington D.C.

http://www.ams.usda.gov/nop/indexIE.htm. Accessed September 7, 2007.

U.S.D.A. 2003. National List of Allowed and Prohibited Substances- National Organic Program. Washington D.C. http://www.ams.usda.gov/nop/ standards/ListReg.html. Accessed September 7, 2007.

U.S.D.A. 2004. U.S.D.A. Processed Verified Program-Agricultural Marketing Service. Washington D.C. http://processverified.usda.gov/1001arc.pdf. Accessed January 22, 2008.

U.S.D.A. 2007. Comments on Naturally Raised Claim for Livestock and the Meat and Meat Products Derived from Such Livestock. Agricultural Marketing Service. Washington D.C. http://www.regulations.gov/fdmspublic/component/ main?main=DocketDetail\&d=AMS-LS-07-0131. Accessed January 22, 2008.

U.S.D.A. 2007. United States Standards for Livestock and Meat Marketing Claims, Grass (Forage) Fed Claim for Ruminant Livestock and the Meat Products Derived from Such Livestock. Agricultural Marketing Service. Washington D.C. http://www.ams.usda.gov/lsg/stand/ GrassFed101607.pdf. Accessed January 22, 2008.

U.S.D.A. 2007. United States Standards for Livestock and Meat Marketing Claims, Naturally 
Raised Claim for Livestock and the Meat Products

Derived from Such Livestock. Agricultural

Marketing Service. Washington D.C.

http://www.ams.usda.gov/lsg/stand/

NRnotice1107.pdf. Accessed January 22, 2008. 